\title{
Methods of economic reliability assessment for industrial enterprise in the market economy conditions
}

\author{
R.A. Timofeev ${ }^{1, *}, V . V$. Shlychkov ${ }^{2}$, and D.R. Nestulaeva ${ }^{1}$ \\ ${ }^{1}$ Kazan State Power Engineering University, KSPEU, Kazan, Russia \\ ${ }^{2}$ Kazan National Research Technical University named after A.N. Tupolev - KAI, KNRTU-KAI, Kazan, Russia
}

\begin{abstract}
The paper dwells upon prospects, topicality and scholarly importance of research into formation and assessment of economic reliability in industrial enterprises as socio-economic systems. The main notions and interconnection of the categories of "stability" and "reliability" of socio-economic systems are presented, based on which the conclusion that these notions are not identical is made. From the standpoint of system-synergetic approach, economic reliability comprises reliability of management system, technical development, conservation activities, human resources management, financial and economic development, marketing activities, and production management. The paper presents main methodological principles of integral estimation of economic reliability of an enterprise in modern conditions. It is suggested to apply E. Harrington's desirability function in order to give a quantitative estimate of economic reliability. In conclusion it is pointed out that assessment of industrial enterprise's economic reliability can become an effective mechanism of assessing the efficiency of harnessing the manufacturer's potential and identifying the reserves and inefficient usage of enterprise resources.
\end{abstract}

\section{Introduction}

The problem of economic reliability of Russian industrial enterprises has become an important issue in domestic economic knowledge only in the last decade. The current interest in this problem is accounted for by transition of Russian economy to market relations, the processes of macroeconomic stabilization in late 1990s [1] and the growing influence of the major world commodity market environment on the industrial reproduction processes [2]. Notwithstanding scientific efforts in this area certain substantive and evaluative issues of economic reliability of industrial enterprises in the real sector of Russian economy have not yet received due theoretical attention and remain unsettled [3].

From the standpoint of sanction wars and international limitation of access to investment resources and new technologies for Russia [4], as well as critical state of real sector of Russian economy [5] the topicality of the given research lies in the following:

- low economic reliability caused by earlier unfulfilled economic tasks is one of the main reasons for bankruptcy of the majority of industrial enterprises [6];

- low financial solvency and, as a result, low economic reliability of the enterprise limit its financial potential making further expansion of production almost impossible [7];

- high probability of faulty operation leads to loss in production process reliability, idle periods and erratic work which, in the long run, increase production costs [8];

- low economic reliability of an industrial enterprise has a negative impact not only on competitiveness of end products but on the competitiveness of the whole enterprise [9].

Thus, the notion of "economic reliability" is not only the main component of enterprise's effective development; it is also a guarantee of its further lucrative existence in market conditions.

Taking into account turbulence in real sector of Russian economy and risks for economically active agents, information concerning estimate of enterprise's economic reliability is in-demand for both internal and external users which determines topicality and viability of systematic research into it.

\section{Problem definition}

Reliability of an industrial enterprise is generally viewed in terms of assessing its technological potential which, in our view, appears unsound. Economically from the standpoint of providing the target competitive power and enterprise efficiency, economic reliability implies not only equipment availability, qualified personnel and potential opportunity to manufacture goods [10] but its stability for political disruptions, management mistakes and business partners' blunders, etc. [11], significantly affecting the process and results of economic activities. An enterprise is considered to be "reliable" or "unreliable" for its business partners depending on its capacity to react adequately and efficiently to external and internal claims. It should be noted that the terms "reliability" and "stability" are not convertible as it is often presumed in the existing literature on the subject.

\footnotetext{
Corresponding author: vestnik_eps@mail.ru
} 
In general, stability is defined as an ability of an object to return to equilibrium after termination of the external forces effect. Nevertheless, an equilibrium system is a closed system with constant parameters. Economically stable enterprise operating on the market and trying to enhance its profitability cannot be in equilibrium as it is constantly developing, therefore, its structure, links and functioning are modifying [12]. Realized value of economic stability is formed by means of overcoming external and internal effects. Due to its specificity, the level of economic stability is a short-term indicator; it is not a long-term given. In the long run, economic reliability of an industrial enterprise must be understood as its ability to operate efficiently and flawlessly for a given period under the current conditions and under the action of constantly changing external and internal factors [13]. Based on the results of the research conducted the authors present main notions and interrelation of reliability and stability of economic and social systems (Table 1).

As can be seen from the above, nonidentity of such categories as "stability" and "reliability" is of theoretical and practical importance as it accounts for the existing differences in the methods of economic stability and reliability assessment for industrial enterprise in market conditions.

Table 1. Main concepts and interconnection of categories of "reliability" and "stability" of economic and social systems.

\begin{tabular}{|c|c|}
\hline Authors & Definition \\
\hline $\begin{array}{l}\text { Dolyatovskiy } \\
\text { V.A., } \\
\text { Dolyatovskaya } \\
\text { V.N. }\end{array}$ & $\begin{array}{l}\text { The category of stability is an ability to } \\
\text { maintain sufficiently small deviations } \\
\text { after perturbation effect. Large } \\
\text { deviations capable of upsetting } \\
\text { system's equilibrium state make the } \\
\text { term "stability" meaningless and should } \\
\text { be treated in terms of system's } \\
\text { reliability [14] }\end{array}$ \\
\hline $\begin{array}{l}\text { Mishin V., } \\
\text { Astashkina I. }\end{array}$ & $\begin{array}{c}\text { Stability is a particular case of system's } \\
\text { reliability [15] }\end{array}$ \\
\hline Popov V.N. & $\begin{array}{l}\text { Reliability as a property of a system } \\
\text { manifests itself as an ability to operate } \\
\text { efficiently, preserving stability of } \\
\text { certain parameters at a given time [16] }\end{array}$ \\
\hline $\begin{array}{l}\text { Tseitlin V., } \\
\text { Stetyukha A. }\end{array}$ & $\begin{array}{l}\text { Economic reliability is an ability of the } \\
\text { system to achieve given economic } \\
\text { result (possible only provided } \\
\text { technological and operational reliability } \\
\text { of the system and its compounds) [17] }\end{array}$ \\
\hline $\begin{array}{l}\text { Kabanov V.N., } \\
\text { MIkhailov S.N. }\end{array}$ & $\begin{array}{l}\text { Economic reliability is understood as, } \\
\text { on the one hand, an ability of an object } \\
\text { to be implemented under certain } \\
\text { interaction with the environment and, } \\
\text { on the other hand, as a quantitative } \\
\text { estimate of an object, explicitly relating } \\
\text { probability with time or other } \\
\text { parameters of the implementation } \\
\text { process [18] }\end{array}$ \\
\hline $\begin{array}{l}\text { Kolokin A.L., } \\
\text { Mikhailov S.N., } \\
\text { Marchenko G.N. }\end{array}$ & $\begin{array}{l}\text { Economic reliability is an economic } \\
\text { state of the system which optimizes the } \\
\text { use of property, economic, financial } \\
\text { and professional resources, its stable } \\
\text { development and settlement of } \\
\text { economic claims and demands of } \\
\text { various interest groups in conditions of } \\
\text { sensible (tolerable) economic risk [19] }\end{array}$ \\
\hline
\end{tabular}

\section{Theoretical part}

In the process of developing methodology for economic reliability assessment the authors addressed an industrial enterprise in terms of system-synergetic approach that allowed presenting it as an economic and social system comprised by a scope of elements, or subsystems, determining aims and conditions of its functioning [20].

Economic reliability of an industrial enterprise is determined by the following elements: reliability of management system, technical development, conservation activities, human resources management, financial and economic development, marketing activities, and production management. Reliability of each subsystem is defined by significant index chosen with the help of Delphi approach or autonomously.

Furthermore, the choice of significant indices is substantiated by strategic factors determining reliability for industrial enterprise's subsystem. In general, the conducted research has demonstrated that all market factors can be divided into:

1. External and internal. External factors affecting the industrial enterprise are the level of economic stability, the level of inflation and unemployment, living standards, social conditions, advances and technological level, state legislation, custom's rules, etc. The internal factors that are connected with manufacturing activities are resource efficiency, resources for output expansion and change of product portfolio, industrial and management structure of an industrial enterprise providing the effect, corresponding to enterprise's objectives and sensitive to market changes.

2. Controlled and uncontrolled. Among the controlled factors are internal and external ones, necessary information about which is obtainable in full measure and within limited time. Uncontrolled factors are determined by lack of necessary information for an industrial enterprise. Meanwhile, in some cases information may be partial or incomplete but limited by time window, for instance, data about competitors, demand tendencies, political changes, etc. It might be problematic to forecast uncontrolled factors and their exact timelines. Therefore, accounting uncontrolled affects is accompanied by certain risk. On the one hand there may be potential losses of enterprise's resources, but on the other hand, the enterprise can derive a significant benefit.

3. Controllable and uncontrollable factors. Controllable factors can be affected. Uncontrollable factors, which can be controlled and uncontrolled, are the ones that the enterprise cannot affect since there are no means or ways to affect them. External factors related to production sphere are mostly uncontrollable and uncontrolled. The control of consumption and distribution factors can be maintained only on condition of data collection vehicle availability even though effect on these factors is limited. Internal factors, as a rule, are subject to control providing proper organization of business and operations.

Thus, the aforesaid contributes to the analysis of underlying determinants of production efficiency. Herewith it becomes obvious that factors determining 
the reliability for each subsystem will have their own nature and significance [21].

The reliability of financial and economic development is conditioned by the following factors:

- Factors for stable financial state of an industrial enterprise and its independence from loans. Among them are inventories, accounts receivable, cash assets, shortterm liabilities, net worth, etc.

- Factors affecting resilient net worth that leave the opportunity to manoeouvre them, including net worth, investments, etc.

- Factors determining stock and expenses by own sources, as well as factors affecting capital investment, production stock and in-process inventory.

Reliability of marketing activities is determined by the factors affecting market share, sales (revenue), storage, shipment and transportation of goods and expenditures for marketing research.

Reliability of management is conditioned by factors determining development strategy, management system and processes, informatization and computerization, and corporate government.

Reliability of environmental activities is determined by:

- Factors characterizing the degree of exceedance of statutory air contamination (impact area, radius of sanitary protection area).

- Factors characterizing the degree of exceedance of emissions release in comparison with permissible exposure limit.

- Factors characterizing the degree of exceeding the real adverse physical impact (noise, ultrasound, infrasound, electromagnetic emanation) as compared to specified value.

- Factors, characterizing population density in the zone of enterprise's negative effect and, consequently, enterprise's potential danger for population (specified population density, average population density in the zone of enterprise's negative effect).

Reliability of the personnel is determined by trust and insistence on high standards among members of staff, business qualities (education, expertise, skills), culture, communicativeness, self-discipline, psychological and physical state.

Based on the conducted analysis, the authors suggest the following scope of strategic indices of economic reliability of an enterprise:

- current liquidity ratio, financial stability index, receivable turnover;

- profitability of sales, return on equity;

- depreciation coefficient of fixed production assets, proportion of monetary assets in enterprise's incoming receivables;

- staff turnover, average monthly wages of 1 employee;

- automation index of management systems;

- amount of fatal industrial accidents;

- index of normative ecological hazard, proportion of environmental payments in product costs.

The proposed methodology of economic reliability assessment is based on determination of the universal scale (wherever possible) for comparing development levels of the object under study and benchmark results.

In accordance with the given statement of the problem we represent the methodology of calculating the economic reliability indices for an industrial enterprise as an economic and social system:

1. The input data:

$X_{i}$ - set of reliability indices for subsystems of an industrial enterprise determining its economic reliability; $i=\overline{1, N}$, where $n$ - the number of indices;

2. Average ratio is calculated as follows:

$$
\bar{X}=\frac{\sum_{i=1}^{N} X_{i j}}{N}
$$

3. Square deviations of indices are calculated in the following way:

$$
\sigma_{i}=\sqrt{\frac{\sum_{i=1}^{N}\left(X_{i j}-\overline{X_{j}}\right)^{2}}{N}}
$$

4. Standardized values of the chosen indices are determined as:

$$
Z_{i j}=\frac{X_{i j}}{\sigma_{j}}
$$

5. Reference values of the indices are set:

$$
X^{*}=\left(X_{1}{ }^{*}, X_{2}{ }^{*}, \ldots, X_{\mathrm{N}}{ }^{*}\right)
$$

6. Standardized values of the references are calculated as:

$$
Z_{j}^{*}=\frac{X_{j}^{*}}{\sigma_{j}}
$$

7. Weights of attributes in economic reliability function are calculated in the following way:

$$
\alpha_{j}=\frac{Z_{j}^{*}}{\sqrt{\sum_{j=1}^{n}\left(Z_{j}^{*}\right)^{2}}}
$$

8. Economic reliability function is formed as follows:

$$
y=\alpha_{1} Z_{1}+\alpha_{2} Z_{2}+\ldots .+\alpha_{n} Z_{n}
$$

9. The value of economic reliability function is attributed to indices value at time:

$$
y_{i}=\alpha_{1} Z_{i 1}+\alpha_{2} Z_{i 2}+\ldots+\alpha_{n} Z_{i n}
$$

10. The value of economic reliability function is calculated at reference values of the indices:

$$
y^{*}=\alpha_{1} Z_{1}^{*}+\alpha_{2} Z_{2}^{*}+\ldots+\alpha_{n} Z_{n}^{*}
$$

11. The level of economic reliability at time $t_{i}$ is determined as [22]: 


$$
S\left(t_{i}\right)=\frac{\sum_{j=1}^{N} \alpha_{j} \frac{X_{i j}}{\sigma_{j}}}{\sum_{j=1}^{N} \alpha_{j} \frac{X_{j}}{\sigma_{j}}} \text { or } S\left(t_{i}\right)=\frac{y_{i}}{y^{*}}
$$

The suggested integral assessment of economic reliability for an industrial enterprise is of dual character. Firstly, an industrial enterprise is capable of achieving potential positive results in its business and operations. Secondly, effective use of its potential guarantees achieving certain results, in other words, actual outcomes of business and operations are a constituent part of business entity's potential. E. Harrington's desirability function was used to measure the economic reliability of an industrial enterprise [23]. The results are shown in table 2.

Table 2. Economic reliability scale of industrial enterprise.

\begin{tabular}{|c|c|}
\hline Values & $\begin{array}{c}\text { Qualitative evaluation of economic reliability } \\
\text { of an industrial enterprise }\end{array}$ \\
\hline [0.76-1] & $\begin{array}{l}\text { High level of economic reliability of an industrial } \\
\text { enterprise }\end{array}$ \\
\hline $\begin{array}{c}0.51- \\
0.75) \\
\end{array}$ & $\begin{array}{l}\text { Stable level of economic reliability of an industrial } \\
\text { enterprise }\end{array}$ \\
\hline $\begin{array}{c}0.36- \\
0.50)\end{array}$ & $\begin{array}{l}\text { Medium level of economic reliability of an } \\
\text { industrial enterprise }\end{array}$ \\
\hline $\begin{array}{c}{[0.21-} \\
0.35) \\
\end{array}$ & $\begin{array}{l}\text { Low level of economic reliability of an industrial } \\
\text { enterprise }\end{array}$ \\
\hline$(0-0.2)$ & $\begin{array}{l}\text { Critical level of economic reliability of an } \\
\text { industrial enterprise }\end{array}$ \\
\hline
\end{tabular}

\section{Conclusion}

The suggested method of economic reliability assessment for industrial enterprise and economic reliability scale allow us to assess reliability and stability of a given enterprise on the market compared to others and the efficiency of its resource use.

The method of economic reliability assessment for industrial enterprise proved effective in assessing the efficiency of harnessing the manufacturer's potential and identifying the reserves and inefficient usage of enterprise resources. In addition, this method can be applied to assessment of industrial enterprise at a given period as well as in the dynamics, which, in its turn, allows to use moment and tempo indices (i.e. duplication of initial indices) to get generalized estimate of economic reliability, characterizing not only the current state but also prospects of socioeconomic development of industrial enterprise in real conditions of Russian economy.

\section{References}

1. V.V. Shlychkov, S.M. Kulishch, R.A. Timofeev, Resource-Based View of Economic Reliability for Industrial Enterprise (Kazan, 2009)

2. R.A. Timofeev, Formation of Economically Reliable Strategy of Developing Industrial Territorial Production

Complex.
http://test.vak.ed.gov.ru/common/img/uploaded/files/Ti mofeevRA.doc.

3. N.V. Vedin, N.F. Gazizullin, A.Sh. Hasanova, Problems of modern economics, 3-4, 39-48 (2003)

4. A.Sh. Hasanova, The Review of Economy, the Law and Sociology, 4, 101-105 (2014)

5. I.G. Alafuzov, R.A. Timofeev, Vestnik of Samara State University of Economics, 8(70), 5-8 (2010)

6. M.N. Smagina, I.G. Alafuzov, The Review of Economy, the Law and Sociology, 3, 90-93 (2015)

7. E.N. Kadyshev, M.E. Kadyshev, V.V. Smirnov, Audit and financial analysis, 2, 317-326 (2012)

8. P.A. Bataykin, Development and realization of a behavioral paradigm of modern Russian Economy Regulation (Moscow, 2014)

9. V.V. Shlychkov, S.M. Kulish, Economic sciences, 54, 277-281 (2009)

10. S.M. Kulish, Kazan Pedagogical Journal, 2(109), 168172 (2015)

11. V.V. Shlychkov, D.R. Nestulaeva, Asian Social $\begin{array}{llll}\text { Science, } & \text { 19, } & \text { 82-89 }\end{array}$ DOI:10.5539/ass.v11n19p82.

12. I.K. Kiyamov, Institutionalization of economic space of the modern Russian state (Kazan, 2012)

13. S.M. Kulish, The Review of Economy, the Law and Sociology, 6, 25-32 (2008)

14. V.A Dolyatovskiy, V.N. Dolyatovskaya, Management Systems Research: Workbook (2004)

15. V. Mishin, I. Astashkina, The Stages of Management Systems Research. http://www.inventech.ru/lib/analis/analis0025/.

16. S.A. Popov, Strategic Management: Understanding is More Important than Knowledge (Moscow, 2003)

17. V. Tseitlin, A. Stetyukha, Transport and Telecommunication, 3, 2, 61-64 (2002)

18. V.N. Kabanov, S.N. MIkhailov, Management in Russia and Abroad, 6, 112-114 (2007)

19. A.L. Kolokin, S.N. Mikhailov, G.N. Marchenko, Proc. Modern Problems of Transforming Economy, Cheboksary, 171-175 (2002)

20. V.V. Shlychkov, A.Sh. Khasanova, N.V. Vedin, Indian Journal of Science and Technology, 8(S10) (2015). DOI: $10.17485 / \mathrm{ijst} / 2015 / \mathrm{v} 8 \mathrm{iS10} / 84883$

21. R.A. Timofeev, Assessment of economic reliability of the enterprise on the basis of management of fuel and energy resources (Ph.D. Dissertation, Nizhny Novgorod, 2005).

22. N.V. Vedin, V.V. Shlychkov, A.Sh. Khasanova, Indian Journal of Science and Technology, 8(S10) (2015). DOI: $10.17485 / \mathrm{ijst} / 2015 / \mathrm{v} 8 \mathrm{~S}$ S10/84877.

23. J. Harrington, Industrial Quality Control, 21(10), 494498 (1965) 